\title{
MACROSEISMICITY AND GEOLOGICAL EFFECTS OF THE WENCHUAN EARTHQUAKE (MS 8.0R - 12 MAY 2008), SICHUAN, CHINA: MACRO-DISTRIBUTION AND COMPARISON OF EMS $_{1998}$ AND ESI $_{2007}$ INTENSITIES $^{2}$
}

\author{
Lekkas, E. \\ ${ }^{1}$ National \& Kapodistrian University of Athens, Department of Geology \& Geoenvironment, Sector of Dy- \\ namic Tectonic Applied Geology, Panepistimioupoli Zografou, Athens 15784, Greece, elekkas@geol.uoa.gr, \\ www.elekkas.gr
}

\begin{abstract}
The Wenchuan earthquake of the $12^{\text {th }}$ of May 2008, in Sichuan county of China can be classified as a large scale event based on the tectonic structures that triggered the earthquake and the effects caused on the human, structural and natural environment. The aim of this paper is to present the geotectonic and seismotectonic regime of the earthquake affected region based on field data along the seismic fault zone and an attempt is made towards the: (i) estimation of the intensity values according to $\mathrm{EMS}_{1998}$ (European Microseismic Scale, 1998) and ESI 2007 (Environmental Seismic Intensity Scale, 2007) and the determination of their geographical distribution in a macroscale, (ii) interpretation of the intensity values data and their distribution according to the seismotectonic, geodynamic and geotechnical regime, and (iii) conduction of a comparative evaluation review on the application of both $\mathrm{EMS}_{1998}$ and $\mathrm{ESI}_{2007}$. The application of both $\mathrm{EMS}_{1998}$ and $\mathrm{ESI}_{2007}$ and the comparative evaluation of the results indicate that the estimated values of $\mathrm{EMS}_{1998}$ and $\mathrm{ESI}_{2007}$ were almost in agreement, despite the fact that the geographical locations of assessment data were different suggesting that the application and use of both scales appears to represent a useful and reliable tool for seismic hazard estimation.
\end{abstract}

Key words: Wenchuan earthquake, China, macroseismicity, geological effects, $\mathrm{EMS}_{1998}, \mathrm{ESI}_{2007}$.

\section{Introduction}

On May 12, 2008, a great earthquake of Ms 8.0 (Mw 7.9) struck south China. This catastrophic event caused many human casualties and heavy engineering damages in a wide area along the Longmenshan fault zone. Numerous buildings collapsed or were damaged to various levels due to the fault displacement extending over $220 \mathrm{~km}$ and the many earthquake related phenomena, such as landslides, rock falls mudslides and liquefactions. The basic lifeline systems such as transportation, electricity, communications, water supply and drainage, gas and hydraulic structures etc, were heavily damaged at a level not previously encountered in Chinese history The heavily damaged roads, bridges, power lines and other systems obstacolated significantly the earthquake relief work, contributing to the human and economic loss.

As reported by the Chinese Ministry of Civil Affairs (September 4), the death toll reached 69,226 casualties and the number of missing was 17,923. Moreover, 374,200 injuries were recorded. The 


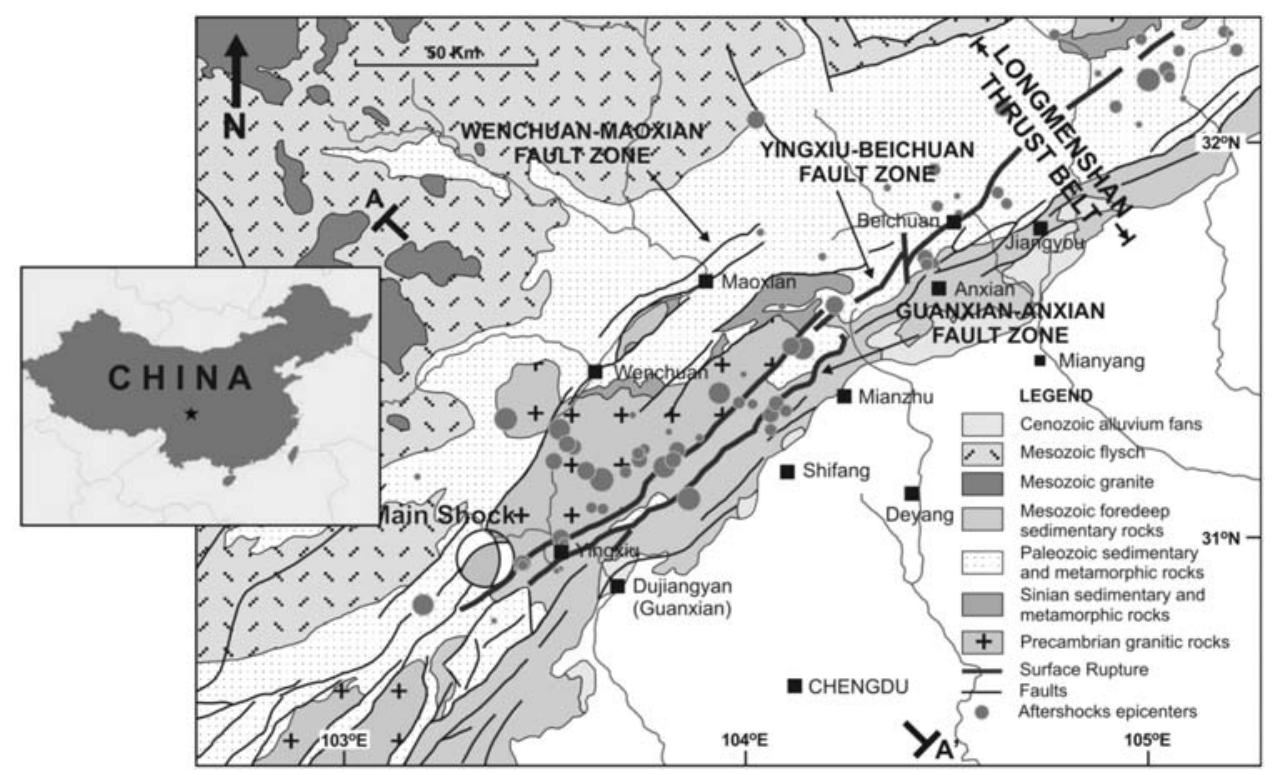

Fig. 1: Geological map of the greater earthquake affected region (12th May 2008) exhibiting the activated faults, the main shock location and the epicenters of the main aftershocks (modified, from Burchfiel et al. 1995, Densmore et al. 2007). For section AA' see Figure 2.

number of homeless people amounted to over 15 million. The percentage of homeless people exceeded $90 \%$ in the inflicted areas of Beinchuan and Qingchuan. The estimated direct economic property loss (including infrastructure) is about 845 billion RMB ( 82 billion $€$ ).

The epicenter of the earthquake was located in Yingxiu town $\left(31.0^{\circ} \mathrm{N}, 103.4^{\circ} \mathrm{E}\right)$ in the southwest side of Wenchuan County, with a focal depth of $14 \mathrm{~km}$ according to the Chinese Earthquake Administration (CEA), $21 \mathrm{~km}$ from Dujiangyan (Guanxian), and $75 \mathrm{~km}$ from the capital of Sichuan province, Chengdu (Fig. 1).

The aims of this paper are: (i) to briefly present the geotectonic and seismotectonic regime of the region affected by the earthquake based on field data along the causative fault, (ii) to estimate the intensity values according to the $\mathrm{EMS}_{1998}$ (Grünthal, 1998) and $\mathrm{ESI}_{2007}$ (Michetti et al., 2007) and to determine their geographical distribution in a mapscale, (iii) to interpret the intensity values data and their evolution according to the seismotectonic, geodynamic and geotechnical regime, (iv) to conduct a comparative evaluation review on the application of both $\mathrm{EMS}_{1998}$ and $\mathrm{ESI}_{2007}$.

\subsection{Geodynamic - Seismotectonic Framework}

This epicentre of this great earthquake was located on the Longmenshan thrust belt, which is a well studied reverse fault zone in the northwest of Sichuan Province (Burchfiel et al. 2008, Chen et al. 2008). This fault zone starts from Luding and Tianquan in the south, extends north-eastwards through Baoxing, Dujiangyan (Guanxian), Beichuan, Jiangyou, and Guangyuan, up to Mianxian of Shanxi Province. The total length is about $500 \mathrm{~km}$, and the width is $40-50 \mathrm{~km}$. The fault zone comprises 3 splays (Figs 1,2). The southern segments of these fault splays are the Guanxian-Anxian Fault, YingxiuBeichuan Fault and Wenchuan-Maoxian Fault respectively (Burchfiel et al. 1995, Densmore et al. 2007). 


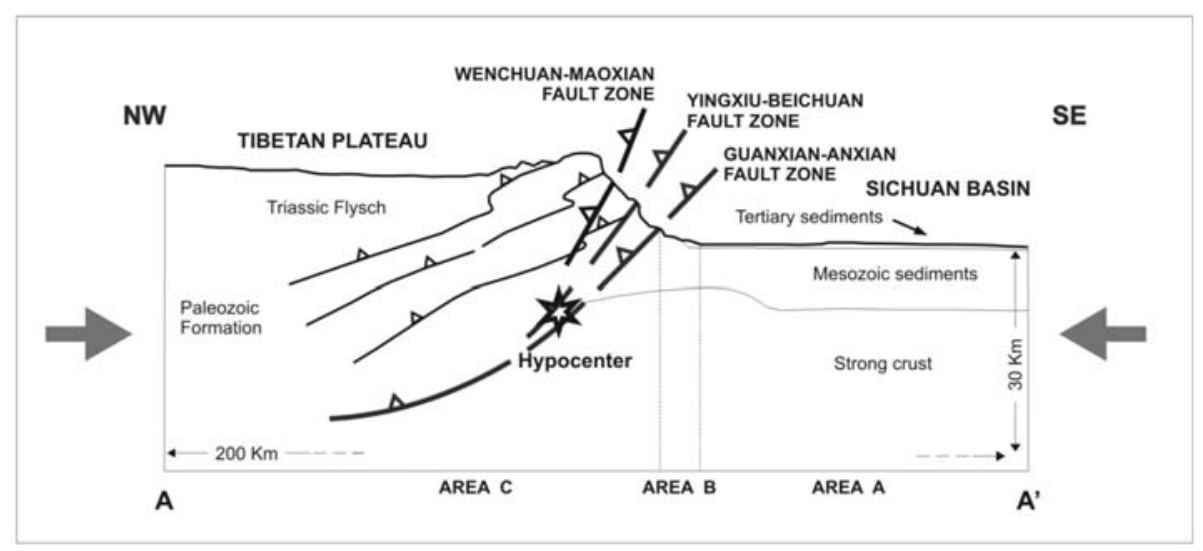

Fig. 2: Geological section trending NW-SE across the tectonic structure of the affected region with the activated faults and the epicenter location. The areas A, B and C are noted to exhibit variations of the intensities values (Burchfiel et al. 1995, Densmore et al. 2007).

The earthquake generated $220 \mathrm{~km}$ of surface rupture along the Yingxiu-Beinchuan fault, characterized by right-lateral oblique slip and $72 \mathrm{~km}$ of surface rupture along the Guanxian-Anxian fault, characterized by reverse slip (Fig. 1). Maximum vertical and horizontal displacements of $6.2 \mathrm{~m}$ and 4.9 $\mathrm{m}$, respectively, were recorded along the Yingxiu-Beinchuan fault, whereas maximum vertical and horizontal displacements of $3.5 \mathrm{~m}$ and $1.0 \mathrm{~m}$, respectively were recorded along the Guanxian-Anxian fault (Hao et al. 2008, Chen et al. 2008). The overall strike of the fault zone is $\mathrm{N} 45^{\circ} \mathrm{E}$, dip angle $50-70^{\circ}$ towards the NW. This large scale fault zone is not only the boundary between Ganqing Block and South China Block, but also the boundary between the mountainous area and the basin of Sichuan. It separates: (i) the extended region of Tibetan Plateau towards the west - northwest with high altitudes exceeding 5,000 $\mathrm{m}$ and (ii) the Sichuan Basin towards the SE representing extended lowland with altitudes that do not exceed $1,000 \mathrm{~m}$.

In conclusion, the distribution of this seismic fault as well as its kinematics and dynamic characteristics are attributed to the geodynamic frame of the greater region, characterized by large scale thrusting of the Tibetan Plateau towards the east on the rigid block of Sichuan Basin. This geodynamic frame is a result of the prevailing compressional regime along the Himalayan Mountain belt attributed to the progression of the Indian plate towards the north. (Burchfiel 2004, Burchfiel et al. 2008, Densmore et al, 2007, Gan et al. 2007, Hubbard \& Shaw 2009, Royden et al. 2008, Tectonics Observatory of Caltech 2008, Zhang et al 2004, USGS 2008).

\section{Intensity Estimation According to $\mathrm{EMS}_{1998}$}

Based on field work and recordings of damages on infrastructure and constructions conducted in an extended region of the order of $50,000 \mathrm{~km}^{2}$ and based on recent publications (Houssam et al. 2008, Sun et al. 2008, Lekkas 2008a, Kabeyasawa et al. 2008), the following values and geographical distribution of intensities according to $\mathrm{EMS}_{1998}$ (Grünthal 1998) were observed.

\section{AREA A}

It mainly corresponds to the extended lowland region of Sichuan Basin (Figs 1,2) with altitudes that do not exceed $1000 \mathrm{~m}$. 
A1. Shifang Region: The Shifang town and the greater surrounding area are located on the morphologically flat area, approximately $15 \mathrm{~km}$ towards the SE of the Guanxian-Anxian fault. It is estimated that $10 \%$ of the buildings collapsed or suffered severe damages, while more that $20 \%$ of the constructions underwent structural damages. These were multistory constructions usually from 2 to 6 floors which probably presented structural imperfections, while there was no systematic geographical differentiation of the collapses within the urban centre. It should be pointed out that the founding substratum corresponds to cohesive Quaternary formations which unconformably lay on the rocky basement of the Sichuan Basin and are not more than $200 \mathrm{~m}$ thick. The estimated intensity value for this region is $\mathrm{VII}_{\mathrm{EMS}-1998}$.

A2. Mianyang Region: The Mianyang region is located on the morphologically lowland section 20$30 \mathrm{~km}$ towards the SE of the fault trace. The recorded damages mainly included fractures on the walls of first floors of modern constructions, while only a small number of multistory buildings collapsed or suffered serious structural damages. These were constructions with up to 6 floors that probably presented structural imperfections and did not follow the modern anti-seismic design regulations. The geological - geotechnical conditions are uniform and do not differentiate from site to site within the urban centre. In the greater area, cohesive Quaternary formations occur that cover older Sichuan Basin formations. The estimated intensity value for this area is on the order of $\mathrm{VI}_{\mathrm{EMS}-1998}$.

A3. Deyang Region: The Deyang Town and the surrounding area is located on the morphologically lowland section, approximately $25-40 \mathrm{~km} \mathrm{SE}$ of the seismic fault. The observed damages in the region mainly include cracks on the walls of the first floors of modern constructions, while a small number of multistory buildings collapsed or suffered severe structural damages. These were constructions, usually up to 5-6 floors, that probably presented structural imperfections and did not follow modern anti-seismic design regulations. In addition, it should be mentioned that the collapses and damages presented random distribution within the urban area. It is estimated that the intensity value in this region is on the order of $\mathrm{VI}_{\mathrm{EMS}-1998}$.

\section{AREA B}

Essentially, this area, 10-20 km wide and $250 \mathrm{~km}$ long (Figs 1,2), corresponds to the elongated region of NE-SW direction that includes the foothills of the Tibetan Plateau and more specifically it is bounded by the flat lowland region towards the southeast of Sichuan Basin and by the trace of the coseismic fault rupture to the northwest.

B1. Dujiangyan Region: The town of Dujiangyan (Guanxian) is located $20 \mathrm{~km}$ east of the epicenter, $50 \mathrm{~km}$ west of the capital city Chengdu, in the zone defined by the boundary between the lowland and the high relief regions. It is located only $5 \mathrm{~km}$ towards the SE of the seismic fault trace. The town develops in its greater extent on a large scale alluvial fan, formed by the Min River that drains a wide mountainous region, while some of its branches run through the town. In the town, approximately 300 constructions totally or partially collapsed while $20 \%$ of the buildings suffered serious construction damages. Mainly multistory buildings collapsed, modern and older, constructed of reinforced concrete. Most collapses were located on the foothills of the mountainous region towards the west and the morphologically higher areas and less on the lowlands. Especially interesting are the new buildings under construction that follow modern anti-seismic design regulation at the higher elevations of the town that collapsed or underwent serious structural damages. In these areas, it seems that the nature of the founding ground which is composed of remnants of river deposits and debris of limited thickness on the rocky background played a determinant role. It is estimated that $30 \%$ of the building collapses observed in this town were located on similar deposits (Fig. 3). Finally it should be mentioned that schools, hospitals and tenths of factories and industrial constructions collapsed in the 

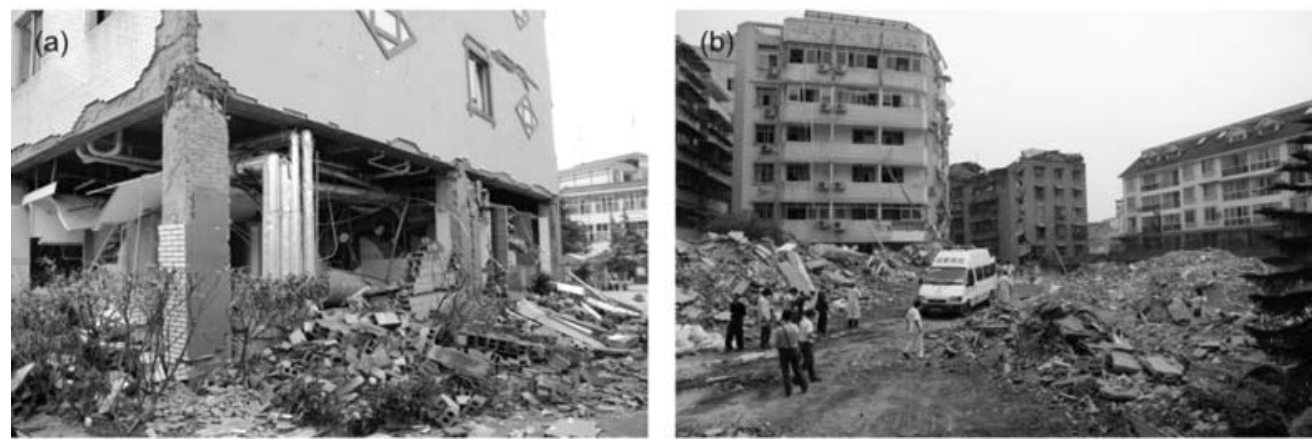

Fig. 3: View of a recently constructed building at the suburbs of Dujiangyan (Guanxian) with serious structural damages on the ground floor props. (type of construction D, damage degree 4) (a) and view of a hospital unit in the same town that totally collapsed (type of construction D, damage degree 5) (b).

greater urban area while all sort of infrastructure suffered serious damage. The estimated general intensity value in the area is on the order of VIII $\mathrm{EMS}_{1998}$, while locally it approached IX $\mathrm{EMS}_{\mathrm{E}-1998}$.

B2. Mianzhu Town: The town of Mianzhu is located $50 \mathrm{~km} \mathrm{NE}$ of the Dujiangyan (Guanxian) town and only $5 \mathrm{~km} \mathrm{SE}$ of the seismic fault. It is estimated that $20 \%$ of the buildings totally or partially collapsed, while $60 \%$ of the buildings suffered considerable damages. The damages are mainly on multistory buildings, modern or older, while constructions with 1 or 2 floors suffered fewer damages. Dominant causes for the damages in many constructions were the architectural mannerism and features, especially in cases of constructions with frames without high level of earthquake resistant design. Moreover, many schools, hospitals and industrial units collapsed causing thousands of casualties while the infrastructure was either destroyed or seriously damaged. The estimated intensity in the area exceeded VIII ${ }_{\mathrm{EMS}-1998}$ and locally approached IX $\mathrm{EMS}_{\mathrm{E}-1998}$.

\section{AREA C}

This region characterized by widespread damage represents the mountainous section of the Tibetan Plateau that includes towards the southeast the outcrop of the seismic fault extending northwest for at least $100 \mathrm{~km}$ (Figs 1,2).

C1. The Beinchuan Regions: The Beinchuan, Hongbai, Hanwaug, Yingxiu, Guanxian, Jiangyou towns as well as smaller settlements, are scattered in the mountainous western section of the affected region. They develop mainly on the morphologically flat areas and especially on older and modern river terraces and on slopes on both sides of the river terraces. Both slopes and river terraces are composed of unconsolidated formations and more specifically by river - stream deposits that are characterized by a dominant presence of pebbles, breccia, and graded material and by recent and older debris as well as fans of variable thickness. The above formations cover in a great extent the Tibetan Plateau formations.

Impressive was the trace of the main branch of the seismic fault (Yingxiu-Beinchuan Fault) from the suburbs of the Beinchuan and Yingxiu towns, while the same branch trace was recorded through the region including the smaller towns of Hongbai and Hanwaug. In those regions and at a zone $150 \mathrm{~m}$ wide around the trace, total collapses of constructions were recorded, even in recent constructions that followed anti - seismic design regulations

The damage suffered by old and new constructions was a result of this above described morpho- 

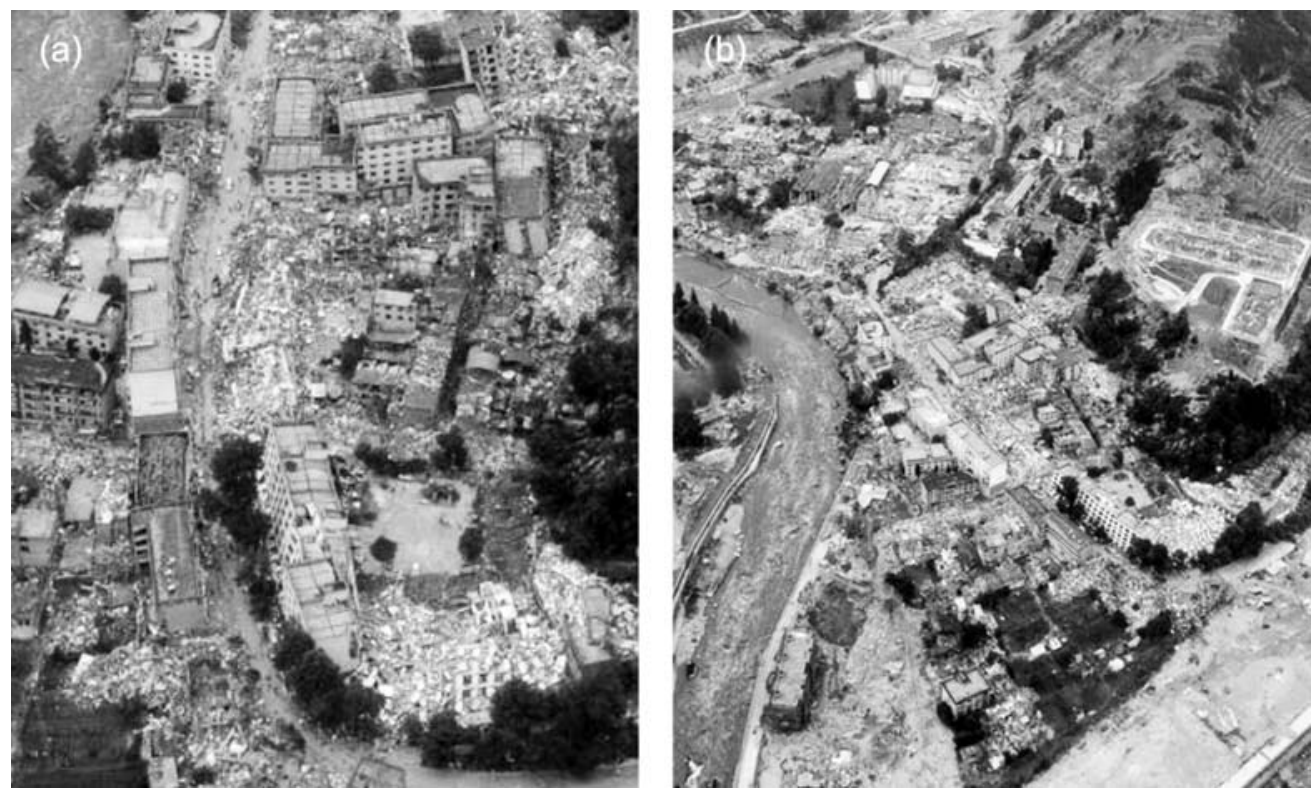

Fig. 4: Oblique aerial view of residential constructions in the Wenchuan and Beinchuan towns that suffered total destruction. These towns were founded on river terraces in the mountainous region. Large scale landslides on the surrounding slopes contributed to the destruction of the residential constructions (Xinhua News Agency China 2008, Reuters 2008).

logical, geological, tectonic and geotechnical framework. In the Wenchuan region, $85 \%$ of the constructions collapsed partially or totally, while the rest suffered significant structural damages. It is indicative that only a few buildings $(<15 \%)$ did not suffer partial or total collapse. The estimated intensity for this region is $\mathrm{XI}_{\mathrm{EMS}-1998}$ while in some locations approached $\mathrm{XII}_{\mathrm{EMS}-1998}$.

C2. Wenchuan Town - Maoxian Town: The Wenchuan and Maoxian towns are located $30 \mathrm{~km}$ west of the activated Yingxiu-Beinchuan fault branch, along the Wenchuan-Maoxian fault branch that was not activated during the earthquake.

In all settlements, the constructions collapsed or suffered considerable structural damage to an extent that exceeded $50 \%$ (Fig. 4). It is indicative that only a small percentage of the constructions, that did not exceed $20 \%$, was left intact. In addition, infrastructures such as bridges, tunnels and dams either collapsed or suffered considerable damage. Finally, in the greater region, landslides and rock falls were recorded due to the high energy relief and the unconsolidated lithologies, that caused additional damage in settlements and infrastructure. The general estimated intensity for this region is $\mathrm{X}_{\mathrm{EMS}-1998}$ and locally approaches $\mathrm{XI}_{\mathrm{EMS}-1998 \text {. }}$

\section{Intensity Estimation according to $\mathrm{ESI}_{2007}$}

Extended observations and recordings were carried out in the study area investigating the primary and secondary effects based on the $\mathrm{ESI}_{2007}$ guidelines (Michetti et al., 2007). Observations of the primary and secondary effects were carried out in a region exceeding $50,000 \mathrm{Km}^{2}$ and are presented for each area from west to east in the following paragraphs. Recent publication data were taken into account (Hao et al. 2008, Lekkas 2008a, Lekkas 2008b, Chen et al. 2008, Zhao et al. 2008). The main results are summarized in Table 1. 

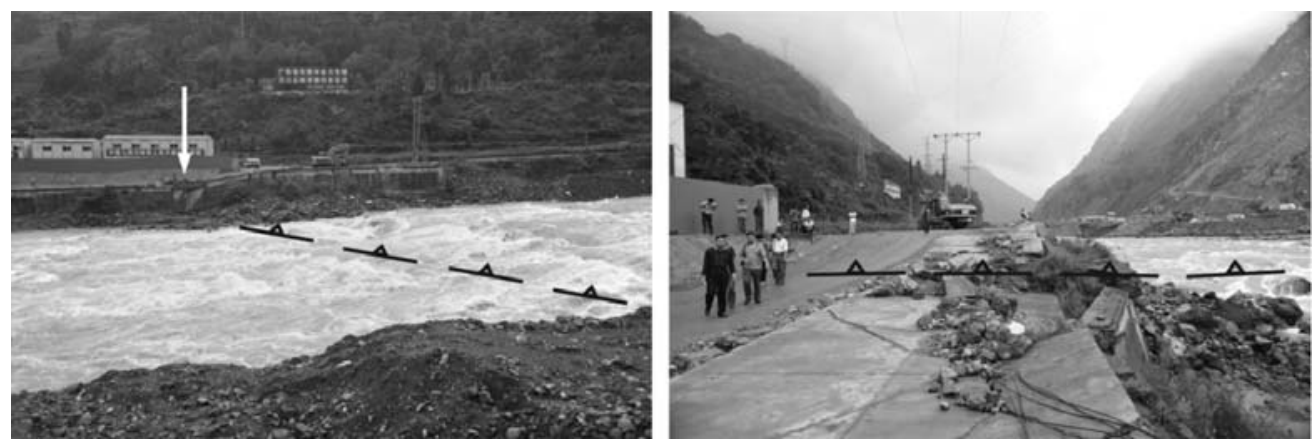

Fig 5: Views of the Yingxiu-Beinchuan seismic fault at the outskirts of Yingxiu town.

\section{AREA A}

A1. Significant variations of the water level in wells and of the flow-rate of springs were locally recorded, as well as small variations of the physical properties of water; turbidity in lakes, springs and wells were also observed.

A2. Fractures up to 5-10 $\mathrm{cm}$ wide and up to hundred meters long were observed, commonly in loose alluvial deposits and saturated soils. Centimeter-wide cracks were common in asphalt roads.

A3. Liquefaction was frequently recorded in the area, depending on local conditions; the most typical effects were: sand boils up to ca. $1 \mathrm{~m}$ in diameter; apparent water fountains in still waters; localized lateral spreading and settlements (subsidence up to ca. $30 \mathrm{~cm}$ ), with fissuring parallel to waterfront areas (river banks, lakes, canals) (Chen et al. 2008).

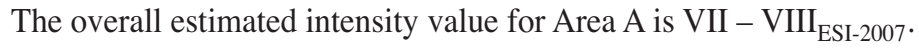

\section{AREA B}

B1. Ground ruptures were recorded, up to a few $\mathrm{km}$ long, with offsets generally in the order of several $\mathrm{cm}$.

B2. Springs changed, generally temporarily, their flow-rate. Some modest springs even run dry. Temporary variations of water level were also observed in wells. Variations of chemical-physical properties of water, most commonly temperature, were observed in springs.

B3. Fractures up to $100 \mathrm{~cm}$ wide and up to hundreds meters long were observed in loose alluvial deposits and saturated soils. Cracks were common in paved asphalt roads, as well as small pressure undulations.

B4. Landslides were widespread in prone areas, also on gentle slopes; as well as rock falls on steep gorges, their size being frequently large $\left(10^{5} \mathrm{~m}^{3}\right)$. Landslides dammed many valleys causing temporary or even permanent small lakes. Many riverbanks, artificial embankments and excavations collapsed.

B5. Liquefaction and water upsurges were frequent; sand boiled up to $3 \mathrm{~m}$ in diameter; the most typical effects being: apparent water fountains in still waters; frequent lateral spreading and settlements (subsidence of more than ca. $30 \mathrm{~cm}$ ), with fissuring parallel to waterfront areas.

B6. Small boulders and tree trunks were thrown in the air and carried away from their site for meters depending on slope angle and roundness, leaving typical imprints in soft soil. 
Table 1.

\begin{tabular}{|c|c|c|c|c|c|c|c|c|c|}
\hline & \multicolumn{5}{|c|}{ PRIMARY EFFECTS } & \multicolumn{3}{|c|}{ SECONDARY EFFECTS } \\
\hline & & $\begin{array}{l}\text { Surface } \\
\text { faulting } \\
\text { and defor- } \\
\text { mations }\end{array}$ & $\begin{array}{c}\text { Hydrologi- } \\
\text { cal anom- } \\
\text { alies }\end{array}$ & $\begin{array}{l}\text { Anom- } \\
\text { alous } \\
\text { waves / } \\
\text { tsunamis }\end{array}$ & $\begin{array}{l}\text { Ground } \\
\text { cracks }\end{array}$ & $\begin{array}{c}\text { Slope } \\
\text { movement }\end{array}$ & $\begin{array}{c}\text { Liquefac- } \\
\text { tions }\end{array}$ & $\begin{array}{c}\text { Jumping } \\
\text { Stones }\end{array}$ & $\begin{array}{l}\text { Total } \\
\text { Area }\end{array}$ \\
\hline \multicolumn{2}{|c|}{ From I to III } & \multicolumn{8}{|c|}{ There are no environmental effects that can be used as diagnostic } \\
\hline VI & $\begin{array}{c}\text { SLIGHTLY } \\
\text { DAMAGING } \\
\text { Modest effects in the } \\
\text { environment }\end{array}$ & & & & & & & & \\
\hline VII & $\begin{array}{c}\text { DAMAGING } \\
\text { Appreciable effects in } \\
\text { the environment }\end{array}$ & & A1 & & A2 & & & & \\
\hline VIII & $\begin{array}{c}\text { HEAVILY } \\
\text { DAMAGING } \\
\text { Extensive effects in the } \\
\text { environment }\end{array}$ & & & & & & A3 & & $10 \mathrm{~km}^{2}$ \\
\hline IX & $\begin{array}{c}\text { DESTRUCTIVE } \\
\text { Effects in the environ- } \\
\text { ment are a widespread } \\
\text { source of considerable } \\
\text { hazard and become im- } \\
\text { portant for intensity as- } \\
\text { sessment }\end{array}$ & B1 & B2 & & B3 & B4 & B5 & B6 & $\begin{array}{c}1000 \\
\mathrm{~km}^{2}\end{array}$ \\
\hline $\mathrm{X}$ & $\begin{array}{c}\text { VERY } \\
\text { DESTRUCTIVE } \\
\text { Effects in the environ- } \\
\text { ment become a leading } \\
\text { source of hazards and } \\
\text { are critical for intensity } \\
\text { assessment }\end{array}$ & & & & & & C6 & & $\begin{array}{c}5000 \\
\mathrm{~km}^{2}\end{array}$ \\
\hline XI & $\begin{array}{l}\text { DEVASTATING } \\
\text { Effects in the environ- } \\
\text { ment become decisive } \\
\text { for intensity assess- } \\
\text { ment, due to saturation } \\
\text { of structural damage }\end{array}$ & & $\mathrm{C} 2$ & $\mathrm{C} 3$ & $\mathrm{C} 4$ & C5 & & C7 & $\begin{array}{c}10000 \\
\mathrm{~km}^{2}\end{array}$ \\
\hline XII & $\begin{array}{c}\text { COMPLETELY DEV- } \\
\text { ASTATING } \\
\text { Effects in the environ- } \\
\text { ment are the only tool } \\
\text { for intensity assessment }\end{array}$ & $\mathrm{C} 1$ & & & & & & & $\begin{array}{c}50000 \\
\mathrm{~km}^{2}\end{array}$ \\
\hline
\end{tabular}


The estimated intensity value for Area B is $\mathrm{IX}_{\mathrm{ESI}-2007}$.

\section{AREA C}

C1. As reported above, this earthquake generated a $220 \mathrm{~km}$ surface rupture along the YingxiuBeinchuan fault and a $72 \mathrm{~km}$ surface rupture along the Guanxian-Anxian fault (Figs 1,5). Maximum vertical and horizontal displacements of $6.2 \mathrm{~m}$ and $4.9 \mathrm{~m}$, respectively, were observed along the Yingxiu-Beinchuan fault, whereas a maximum vertical displacement of $3.5 \mathrm{~m}$ occurred along the Guanxian-Anxian fault (Hao et al., 2008).

C2. Many springs significantly changed their flow-rate and elevation of outcrop. Additionally, many springs run temporarily or even permanently dry. Temporary or permanent variations of water level were observed in wells. Strong variations of physical properties of water, most commonly temperature, was observed in springs. Water became very muddy in large basins, rivers, wells and springs.

C3. Intense water undulations were recorded in the lakes of the area either due to the earthquake tremor or due to landslides triggered at the banks. It is worth mentioning that at the artificial lake of the Zipingpu dam the waves caused by the extensive landslides in the surrounding mountains exceeded 10 meters in height causing the death of about 100 fishermen.

C4. Open ground cracks up to several meters wide were very frequently recorded, mainly in loose alluvial deposits. In competent rocks they did not exceed $1 \mathrm{~m}$.

C5. Large landslides and rock-falls $\left(>10^{5}-10^{6} \mathrm{~m}^{3}\right)$ were frequently recorded, practically regardless of equilibrium state of slopes (Figs 6,7), causing many temporary or permanent barrier lakes. River banks, artificial embankments, and sides of excavations collapsed. Levees and earth dams incurred serious damages (Lekkas 2008b, Zhao et al. 2008, Xu et al. 2009).

C6. Liquefaction, with water upsurge and soil compaction was recorded, that changed the aspect of wide zones; sand volcanoes more than $8 \mathrm{~m}$ in diameter, vertical subsidence $>3 \mathrm{~m}$, large and long fissures due to lateral spreading were common.

C7. Big boulders with diameter of several meters were thrown in the air and moved away from their site for long distances down even gentle slopes.

The estimated intensity values for Area $\mathrm{C}$ range from $\mathrm{X}$ to $\mathrm{XII}_{\mathrm{ESI}-2007}$ (Fig. 7).

\section{Discussion and Conclusions}

The earthquake of the 12th of May 2008 in Sichuan county of China can be classified as a large scale event based on the size of the tectonic structures that triggered the earthquake and the effects caused on the human and natural environment.

Intensity values could be estimated for a broad area around the epicentre based on $\mathrm{EMS}_{1998}$ and $\mathrm{ESI}_{2007}$ (Figs 7, 8).

Area A is characterized by intensities VI-VII ${ }_{\mathrm{EMS} 1998}$ as a result of its relative distance from the seismic fault, the flat relief and relatively favorable geotechnical conditions and of course the development of the area on the footwall that Sichuan basin represents. As a result of the above, the damages in constructions were restricted and in general were decreasing towards the east - southeast, as the horizontal distance from the seismic fault and the epicenter was increasing. In the area values of

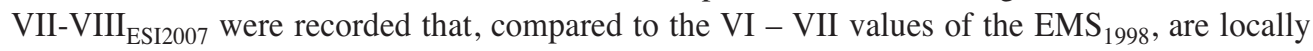
higher by one degree mainly as a result of the widespread liquefactions, hydrological changes and 

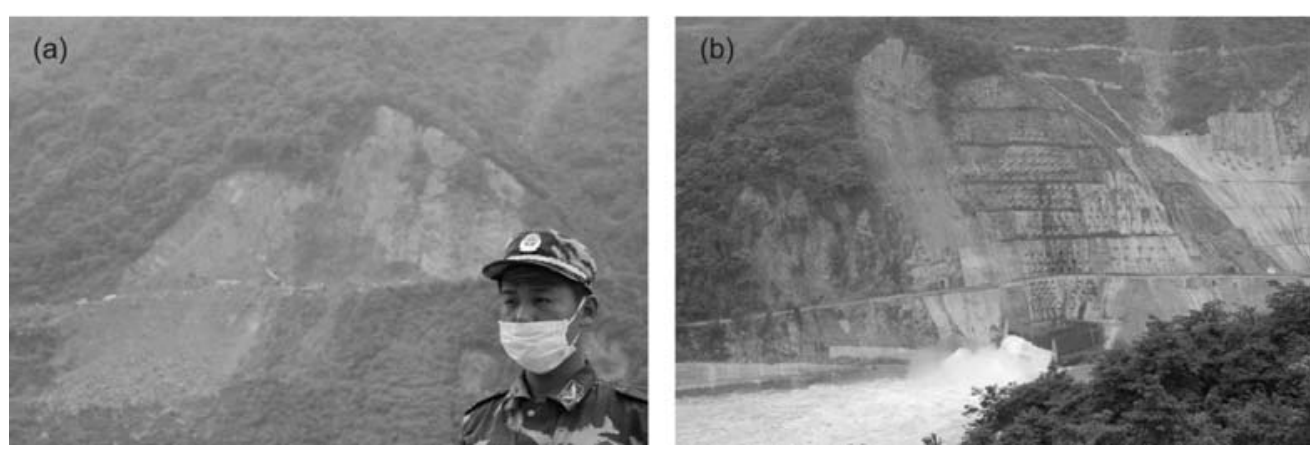

Fig. 6: View of large-scale landslides that were triggered in the mountainous region along river Min (a) and view of the Zipingpu Dam (b).
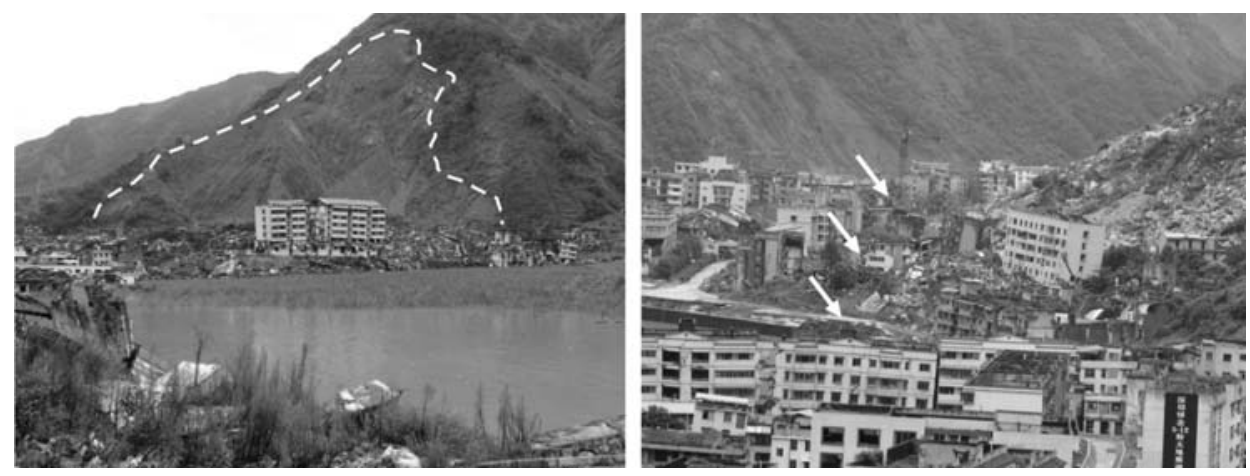

Fig. 7: Views of Beinchuan town which was almost totally destroyed $\left(\mathrm{ESI}_{2007}=\mathrm{XI}, \mathrm{XII}\right)$ due to the combined action of the seismic fault Yingxiu-Beinchuan (arrows) and the huge landslides.

ground failures. Nevertheless, in general, there is an agreement in the intensity values of both $\mathrm{EMS}_{1998}$ and $\mathrm{ESI}_{2007}$ for Area A.

Area B corresponds to the intermediate morphological zone between the high relief of Tibetan Plateau to the northwest and the Sichuan Basin to the southeast bounded towards the northwest by the trace of the seismic fault. It is characterized by a complex relief with characteristics corresponding mainly to rivers, alluvial deposits and debris fans. Here, the values according to EMS $_{1998}$ reached VIII and only locally approached IX, while the values according to the $\mathrm{ESI}_{2007}$ reached IX. The highly developed hydrographic network, the high water table, the unconsolidated, partly cohesive material of the alluvial deposits and the intense phenomena of erosion and deposition of unconsolidated material created an adverse geotechnical setting for the development of urban centres. As well, these factors favored the triggering of secondary phenomena and intense morphological changes that affected directly the values of $\mathrm{ESI}_{2007}$.

Area C corresponds to the portion of Tibetan Plateau characterized by high relief, steep slopes, dense river network, deep erosion and intense phenomena of erosion. It includes the tectonic structure activated during the earthquake and develops towards the west corresponding essentially to the causative fault hanging wall. In area C, the EMS ${ }_{1998}$ and $\mathrm{ESI}_{2007}$ intensity values are generally in agreement. The values X-XII ${ }_{\mathrm{EMS}-1998}$ represent extended collapses of constructions due to the un- 


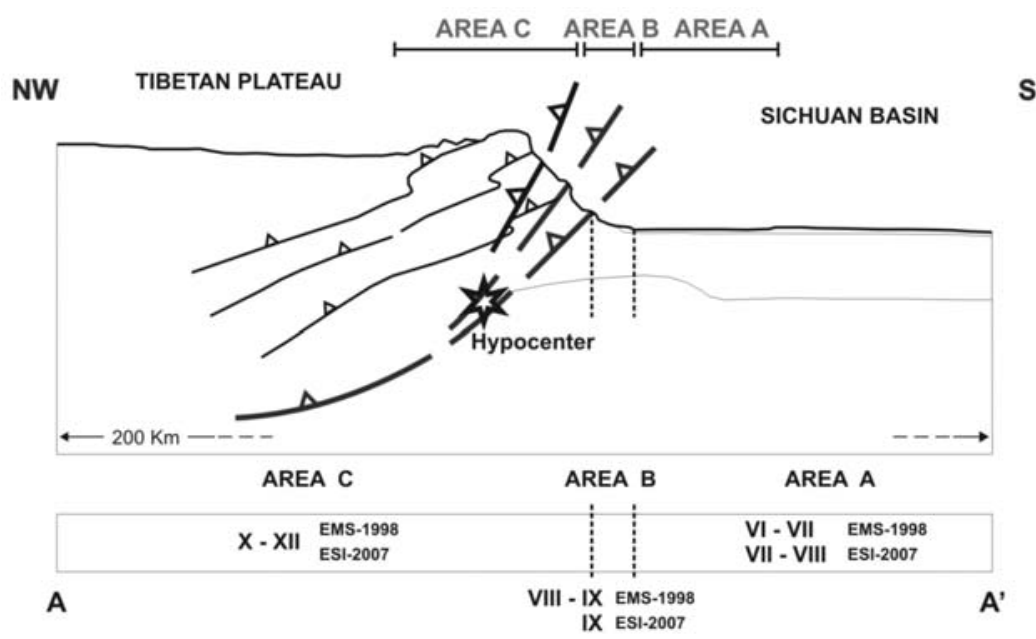

Fig. 8: Schematic cross-section NW-SE trending with the location of areas A, B and C and the estimated values according to $\mathrm{EMS}_{1998}$ and $\mathrm{ESI}_{2007}$ intensity scales.

favorable geotechnical and geomorphological conditions and to diffuse landslides. The values of $\mathrm{X}-\mathrm{XII}_{\mathrm{ESI}-2007}$ derive from the presence of the fault trace at surface and the secondary effects that developed in numerous places such as ground ruptures, large-scale landslides and tsunamis in lakes as a result of the geomorphological conditions, the negative geotechnical conditions and the complex geological setting.

Summarizing, by the application of both $\mathrm{EMS}_{1998}$ and $\mathrm{ESI}_{2007}$ and the comparison of the results based on the geodynamic, seismotectonic, geomorphological and geotechnical frame of the region affected by the 12th of May, 2008 earthquake, the following conclusions can be drawn (Fig. 8):

No significant variations on the values of both intensity scales were recorded during their application for the areas A, B and C, that correspond to three clearly distinct areas: (i) the flat lowland area of Sichuan Basin, located southeast of the trace of the seismic fault, (ii) the elongated area of a general northeast - southwest direction with special morphological characteristics, located to the southeast of the seismic fault trace and (iii) the region that includes the occurrence of extensive surface faulting to the west and corresponds to the Tibetan Plateau.

The value variations in both scales that were estimated between the footwall (area A) and the hanging wall (area C) are of the order of 2 to 4 degrees. At the elongated zone (area B) to the southeast of the activated fault zone intermediate values were estimated.

So the application and use of both $\mathrm{EMS}_{1998}$ and $\mathrm{ESI}_{2007}$ represent a fundamental tool for the estimation of seismic hazard in a region and should be encouraged. In particular, the $\mathrm{ESI}_{2007}$ could be applied to past, even prehistorical events time frames since it is based on geological effects not biased by cultural/technical differences either in time and space.

\section{References}

Burchfiel, B.C. (2004). New Technology, New Geological Challenges. GSA Today, 14, No.2, 4-7.

Burchfiel, B.C., Chen, Z., Liu, Y. and Royden, L.H. (1995). Tectonics of the Longmen Shan and adjacent regions, central China. International Geological Review: 37 661-738. 
Burchfiel, B.C., Royden, L.H., Van der Hilst, R.D. and Hager, B.H. (2008). A geological and geophysical context for the Wenchuan earthquake of 12 May 2008, Sichuan, People's Republic of China. GSA Today, 18, No.7. 4-11.

Chen, L., Hou, L., Cao, Z., Yuan, X., Sun, R., Wang, W., Mang, F., Chen, H., and Dong, L. (2008). Liquefaction Investigation of Wenchuan Earthquake. 14th WCEE, Beijing, China, S31-049.

Densmore A.L., Ellis, M.A., Li, Y., Zhou, R., Hancock, G.S., and Richardson, N. (2007). Active tectonics of the Beinchuan and Pengguan faults at the eastern margin of the Tibetan Plateau. Tectonics. 26 TC4005, doi:10.1029/2006TC001987.

Gan, W.J., Zhang, P.Z., Shen, Z.K., Niu, Z.J., Wang, M., Wan, Y.G., Zhou, D.M., and Cheng, J. (2007). Present-day crustal motion within the Tibetan Plateau inferred from GPS measurements. J. Geophys. Res. - Solid Earth. 112 B08416, doi:10.1029/2005JB004120.

Grünthal, G. ed. (1998). European Macroseismic Scale 1998. Conseil de l'Europe, 1599.

Hao, K.X.S., Si, H. and Fujiwara, H. (2008). A Preliminary Investigation of the Coseismic Surface-Ruptures for Wenchuan Earthquake of 12 May 2008, Sichuan, China. 14th WCEE, Beijing, China, S31007.

Houssam, M.A., Li, Y., Oday, A.S., A'ssim, A. and Wang, L. (2008). A Comprehensive Analysis Of The Devastating Wenchuan Earthquake Of May 12th 2008. 14th WCEE, Beijing, China, S31-014.

Hubbard, J., and Shaw, J. (2009). Uplift of the Longmen Shan and Tibetan plateau, and the 2008 Wenchuan (M=7.9). Nature, 458 194-197.

Kabeyasawa, T., Kabeyasawa, T., Kusunoki, K. and Li, K. (2008). An Outline of Damages to School Buildings in Dujiangyan by the Wenchuan Earthquake on May 12, 2008. 14th WCEE, Beijing, China, S31-002

Lekkas, E. (2008a). Wenchuan Earthquake (Mw 7.9, 12 May 2008) Sichuan, China. Geotectonic Regime and Damage Macro-Distribution. 14th WCEE, Beijing, China, S31-015.

Lekkas, E. (2008b). Zipingpu Dam Failures (Sichuan Prefecture, China) caused by the 7.9R Earthquake on the 12th May 2008. ESC 2008, 31st General Assembly, Crete Island, Greece, 238-239.

Michetti A.M., Esposito, E., Guerrieri, L., Porfido, S., Serva, L., Tatevossian, R., Vittori, E., Audemard, F., Azuma, T., Clague, J., Comerci, V., Gürpinar, A., Mccalpin, J., Mohammadioun, B., Mörner, N.A., Ota, Y., Roghozin, E. (2007). Environmental Seismic Intensity Scale 2007 - ESI 2007. In: Guerrieri L. and Vittori E. (Eds.), Memorie Descrittive della Carta Geologica d'Italia, 74, 7-54, Servizio Geologico d'Italia - Dipartimento Difesa del Suolo, APAT, Roma, Italy.

Royden, L.H., Burchfiel, B.C. and Van der Hilst, R.D. (2008). The geological evolution of the Tibetan Plateau. Science, 321. no. 5892, 1054 - 1058.

Sun, J., Q. Meng, Ma, Q., Shi, H. and Sun, Z. (2008). Outline introduction of building damage in high intensity areas of Wenchuan M8.0 earthquake. 14th WCEE, Beijing, China, S31-020.

Tectonics Observatory of Caltech (2008) The science behind China's 2008 Sichuan earthquake. http://www.tectonics.caltech.edu/outreach/highlights/2008MayChinaEQ/index.html.

USGS (2008). Magnitude 7.9 - Eastern Sichuan, China http://earthquake.usgs.gov/eqcenter/eqinthenews/2008/us2008ryan/.

Xu, Q., Fan, X.M., and Westen, C.V. (2009). Landslide dams triggered by the Wenchuan Earthquake, Sichuan Province, South West China. Bull Eng Geol Environ, 68, No. 3, 373-386.

Zhang, P.Z., Shen, Z., Wang, M., Gan, W.J., Burgmann, R. and Molnar, P. (2004). Continuous deformation of the Tibetan Plateau from global positioning system data, Geology, 32 809-812.

Zhao, J., Zhou, Z. and Wu, J. (2008). Investigation of landslide and rockfall caused by Wenchuan earthquake of Ms8.0. 14th WCEE, Beijing, China, S31-050. 